\title{
RESEARCH OF THE INTELLIGENT RESOURCE SECURITY OF THE NANOECONOMIC DEVELOPMENT INNOVATION PARADIGM
}

\author{
Tetiana Ostapenko ${ }^{1}$, Igor Britchenko ${ }^{2}$, Peter Lošonczi ${ }^{3}$
}

\begin{abstract}
The resources and resource potential of the innovative component of nanoeconomics are analyzed. The factors of production - classical types of resources such as land, labor, capital and technology - are described. Ways of influencing the security resources of nanoeconomics within the innovation paradigm are evaluated. The purpose of the study is to identify the factor of nanoeconomics in the formation of resource security potential in the innovation paradigm. To achieve this goal, the following tasks were set: to characterize the importance of the land resource as a factor in the potential of economic nanosystems; to highlight the importance of capital as a factor of nanoproduction and an indicator of the innovation paradigm; to determine the labor resource in the development of innovative nanosystems; to analyze the intellectual potential of nanoeconomic development of the innovation paradigm; to identify clusters of innovative nanopotential in the regions of countries with transition economies. Each resource is examined separately with the first analysis of a resource security assessment such as land. The other resource under consideration is labor. Demographic factors become decisive in describing the development of labor resources. The capital factor allows the formation of independent economic systems, when the state budget affects the possibility of developing science, education and health care. A number of methods were applied during the study: methods of induction and deduction (to assess the importance of the innovation paradigm for the development of nanoeconomics); system analysis and structural approach (to determine the aggregate state of production factors); method of comparing the quality of production factors in market economies and in developed countries; an observation method (for assessing the state of resources in different countries); method of cluster analysis (to determine the existence of innovation-territorial regions in countries with economies in transition). The analysis is carried out to identify the conditions of the impact of production factors on the innovative paradigm of nanoeconomics. It reveals theoretical approaches to the formation of nanoeconomics and its active development. As a result of the study of intellectual and resource potential of security, a cluster analysis was carried out to assess the conditions for the formation of innovation-territorial regions. This study allows to understand the role of production security factors in the formation of the innovation paradigm and the efficiency of the development of nanoeconomics. The way of providing the basis for the development of nanoeconomics in the form of efficient use of production factors is considered as a perspective.
\end{abstract}

Key words: intellectual-resources security, innovation paradigm, nanoeconomics, factors of production, innovation clusters.

JEL Classification: D11, F63, 131, L60, O10

\section{Introduction}

In the modern conditions of economic science development, the human factor plays a decisive role in the development of economic systems of different levels. The lowest system is nanoeconomics, which is defined as a human economy. Its innovative basis is the innovation paradigm with the determinants of intellectual and resource security. The determinants

\footnotetext{
Corresponding author:

${ }^{1}$ National Aviation University, Ukraine.

E-mail: ostapenco@ukr.net

ORCID: https://orcid.org/0000-0003-2032-1365

${ }^{2}$ State Higher Vocational School Memorial of Prof. Stanislaw Tarnowski in Tarnobrzeg, Poland.

E-mail: ibritchenko@gmail.com

ORCID: https://orcid.org/0000-0002-9196-8740

${ }^{3}$ University of Security Management in Košice, Slovakia.

E-mail: peter.losonczi@vsbm.sk

ORCID: https://orcid.org/0000-0003-3944-8462
} 
of resource supply are vital for the development of any production system. Factors of production are the primary resource endowment for the creation of goods and services within the production processes of the real sector.

The nature of the nanoeconomy is defined along with the characteristics of the factors of production. Thus, it implies the identification of the individual as owner, producer, and consumer. The owner is the bearer of factors of production, the producer is their user, and the consumer is the modifier of factors of production in finished goods and services. The factors of production in the nanoeconomy allow the creation of goods by individuals (scientific and technological personnel) for technology development; production personnel (for the use of technology in flow production); and sales personnel (for the purchase and sale of finished goods and services). In the process of expanded reproduction (from scientific development to realization to the final consumer) of the nanoeconomy certain persons are involved, who conduct this process and ensure production at its various levels. To determine the quality of production factors in Ukraine, it is necessary to compare them with the availability of resources in the countries of the European continent as the main partners of the economy in transition.

The land factor is crucial for the development of the agro-industrial complex and the solution of the food problem. Most of the industrialized countries of the world are fully self-sufficient in agricultural products. At the very beginning of their joint existence, EU countries formed a Common Agricultural Policy (CAP) aimed at 100\% self-sufficiency in food. Throughout the 1960s and 1970s, agricultural production gradually adjusted.

The land factor in Ukraine is comparable to that of France, since agriculture is the most important sector of the transition economy in a country like Ukraine. Meanwhile, France is the leader of agribusiness in the EU.

When it comes to civil engineering, land is used for construction. The territory of former plants and factories is used for housing, and new industrial enterprises are built on the outskirts of settlements with the conversion of existing facilities. The land resource is defined in nanoeconomics as the basis for wealth management.

Capital as a factor of production is necessary for the safe development of production at the national and nanoscale. This factor of production makes it possible to acquire other necessary resources and form working capital.

The capital factor in transition economies (such as Ukraine) is compared to the situation in Great Britain, the country with the highest quality of capital in the world and Western Europe in particular.
Workforce is also a security resource for the production of certain goods. This security resource is directly related to the nanoeconomy because it is human. Human labor becomes the basis for the development of the production of goods and services. On the other hand, humans are their main consumers. The labor resource differs from the nanoeconomy in that the former is analyzed as labor. It is also viewed as the cost of producing certain goods, while nanoeconomics is a whole system, reflecting both production and consumption from the moment a person is born until retirement.

The intellectual security resource (or technology) is also critical to economic growth. The more innovative production is, the more opportunities for economic systems to develop and grow. All types of factors of production are the basis of innovative development, and the latter is the basis for long-term growth prospects within the national economy and the nanoeconomy.

Thus, the problem of security of intellectual-resource impact of innovation paradigm on the development of nanotechnology economy becomes the key to activate national innovation systems. The relevance of this issue is due to the fact that the individualization of economic processes outlines the merging of economic systems of different levels and forms the dependence of economic and innovative subjects on the subjective factor.

\section{Analysis of recent researches and publications}

Various scholars around the world have paid attention to the question of shaping the innovation paradigm. Thus, the researcher (Rylach, 2016) notes that innovation is one of the most important categories of the modern economic paradigm. There are some authors (Schumpeter, 2011) who have begun to use this category in science and practice. Other authors (Bazhal, 2015), (Tugan-Baranovsky, 1894) have outlined the stages of formation of the innovation paradigm since the early $20^{\text {th }}$ century, enriching these studies with such components as long waves (TuganBaranovsky, 1894) and scientific and technological structures (Bazhal, 2015). The technical and economic structure is characterized by certain key factors and the nature of the development of industries during the life cycle of this structure. Mixed economy is important (Bazhal, 2015). A theory has also been developed in which education is a growth factor. Such authors have found that one of the factors of economic growth is special education (Bazhal, 2015); emphasizing the availability of highly educated professionals as a major factor in economic development (Bazhal, 2015). Technological progress is an exogenous factor of economic development. 
Regarding the types of resources that are used to expand knowledge, the author (Rylach, 2016) identifies the following: research and development, technology development and production, learning, human development activities, learning by doing.

In general, models of endogenous economic growth and the innovation paradigm fall into several groups (Rylach, 2016):

a) models in which the production of innovation is represented as a product produced in the RED process;

b) activities directed at the individual which increase human capital;

c) learning-by-doing models;

d) models of international trade and technology diffusion;

e) models of technological progress and population;

f) models of inequality and economic growth.

Various authors note that a systematic analysis, which originated in the 1990s, is used in the study of the innovation paradigm. Innovation networks and innovation systems are also studied separately.

Another author (Zabarna, Kozakova, 2019) defines the paradigm of innovative development in a market transformation. The following issues are also identified: innovative development at the meso level, theoretical and methodological principles of innovation, processes of formation and development of innovative activity, development of innovation as a component of the innovation process, as well as the strategic direction of innovation activity.

The researcher (Kotko, 2016) defines the innovation ecosystem as a new paradigm of innovative economic development. The author forms approaches to the relationship of environmental, economic and social factors in the development of the ecosystem with the innovation paradigm as the basis of the ecosystem.

The analyst (Zhyhalkevych, 2014) notes that the paradigm is the original system of views, in particular on the formation of clusters. The paradigmatic basis of cluster formation is determined by the following components:

- geographic concentration;

- the multitude of economic agents;

- the functional interconnection and interaction of the participants;

- specialization of companies (cluster subjects);

- the competition within the cluster;

- availability of highly qualified staff.

These issues are crucial for the influence of nanoeconomics on the creation of an innovation paradigm within national economic systems. It should be noted that recently the nano-agent has been seen more as a priority in the system of "human - society" relations. The individualization of such relations subjectively affects the development of national economic and innovation systems. The author (Arrow, 1974) was the first to introduce the term "nanoeconomics" as an economic category. At this stage of the development of economic science, this category is increasingly becoming the object of research in various fields. The influence of nanoeconomics on the formation of the innovation paradigm is an issue not fully disclosed in the scientific sources. The relevance of its research is the basis for the development of an individualized factor in the formation of innovative approaches to the national economic system.

\section{Purpose and objectives of the study}

The purpose of the study is to determine the factor of nanoeconomics in the formation of the resource potential of security within the innovation paradigm.

In order to achieve this goal, the following tasks were set:

- to characterize the significance of the land resource as a factor in the security potential of economic nanosystems;

- to emphasize the importance of capital as a factor of nanoproduction and an indicator of the innovation paradigm;

- to determine the labor resource in the development of innovative nanosystems;

- to analyze the intellectual potential of the nanoeconomic development of the innovation paradigm;

- to identify clusters of innovation nanopotential in the regions of countries with economies in transition.

\section{Sources and methods of research}

A number of methods were applied during the study: methods of induction and deduction (to assess the importance of the innovation paradigm for the development of nanoeconomics); system analysis and structural approach (to determine the aggregate state of production factors); comparison method (to compare the quality of production factors in market economies and in developed countries); method of observation (to assess the state of resources in different countries); method of cluster analysis (to determine the existence of innovative and territorial regions in countries with economies in transition).

\section{The results of the study of the influence of the quality of production factors on the innovative paradigm of nanoeconomics}

\subsection{The study of the land resource as a factor in the potential of economic systems}

Having identified the main components of nanoeconomics, its subject matter can be characterized as nanoeconomics. It is a human economy, which stipulates that its productive force is man, the interconnection is the process of acquiring the skills of 
economic behavior by children and adults. It is aimed at ensuring high competitiveness and dissemination of experience in the economic environment of the country.

Nanoeconomics is different from nanotechnology economics, where the latter means the development, processing and introduction of nanotechnology into the production process. Nanotechnology economics is a component of nanoeconomics. The latter consists of child economics, human economics and nanotechnology economics. First of all, the leading link in the nanoeconomy is the human being. The child economy covers the whole period from birth to graduation. It is a new person who uses certain resources for his or her maturation and subsistence, which takes place with the help of the household in which the person lives and develops. It is a whole industry of childhood that produces goods and services for children and the rising generation. It is also a system of educational process and upbringing.

The second component of the nanoeconomy is the human economy. This component implies an effort to achieve a high quality of life. Thus, human capital is a resource for improving life. For some, it is entrepreneurial capital, where ownership becomes the key to improving quality of life. Free capital becomes the basis for the formation of entrepreneurship, and the latter becomes the basis for increased profits. When it is not entrepreneurship, a person is usually a wage laborer who sells his labor to provide a high quality of life for himself and his family. In this case all resources are used: labor, land, capital and technology.

The third component of the nanoeconomy is the economy of nanotechnology, which is a type of innovation economy. A person, who is an entrepreneur or an employee, is engaged in the development of nanotechnology solutions. This process also requires production factors. Thus, nanotechnology develops on the basis of previously invented technologies, forming a new nanostructure. It is well known that appropriate financial support is necessary for such developments, since without capital it is impossible to carry out expensive research. In order to create the basis for the production of new materials, processes, and goods, appropriate raw materials must be available. In addition, the human factor of production implies that only highly qualified specialists can produce appropriate nanotechnology.

Some authors (Porter, 2018) emphasize that factor parameters are a determinant of national economic competitiveness development. These factors of production are land, labor, capital and technology. It is known that all factors are divided into basic and developed, general and specialized. The basic ones are those that are used inefficiently. For example, in the early 1990s and 2000s, land was used inefficiently in some transition countries, as 30 centners per hectare were harvested, despite the fact that this land is the most fertile in the world. Meanwhile, on brown soils of France harvested up to 70 quintals per hectare, which is an effective use of this production factor, taking into account the resource being developed (Dziubanovska, 2019).

Common factors are used in many areas. For example, in the 1990s, labor could be seen as a common resource in transition countries because there were specialists and no jobs for them. People retrained and moved to areas where they could find work. Unlike in the U.S., where there is a narrow specialization of specialists, moving into a new field requires retraining, which is a specialized resource (Nosachevska, Afanasyeva, 2019).

The analysis of the factors of production in selected countries with economies in transition is worth making a model country with a transition economy and a system of development of nanoeconomic principles.

Agricultural areas in these countries are used quite effectively. Thus, cereals and legumes occupy the largest areas and provide the largest volume of production, but the volume of yields is not high enough and amounts to almost 30 quintals per hectare. The volume of the potato crop is high and shows a positive trend year after year. The volume of fruits and vegetables is also increasing, so more and more of these products are being exported.

Entrepreneurs in the agricultural sector are quite active, and individual entrepreneurs have a significant share in the production of various crops. It can also be seen that the total number of enterprises engaged in the cultivation of grain and legume crops is 34,673 units. This is a high figure with a significant share $(61 \%)$ of small agricultural businesses occupying up to $100.00 \mathrm{~m}^{2}$. Accordingly, a small number of large agricultural enterprises harvest significant crops and form their grain profile (Oliynyk-Dunn, Wasilewski, 2020). Thus, the harvest volume of large agricultural enterprises varies from 50 to 65 centners per hectare, and small agribusiness collects 35.8 quintals per hectare. The smaller the agribusiness enterprise, the less crop is harvested with the smallest harvest volume indicator.

The nanofactor of agricultural business development is also important when analyzing approaches to security resources within the innovation paradigm. Thus, the number of organizations performing research in the field of agriculture, forestry and fisheries was 14 institutions in 2017 and 7 institutions in 2019. As can be seen, there has been a decrease in the indicators by half. This is a negative trend, which indicates a decrease in the role of the agricultural sector for innovative development of the economy as a whole. The nanofactor provides the distribution of the number of workers engaged in the implementation of scientific research. There are only 79,262 people in 
transition countries, of whom 6,508 are employed in agriculture, which is $8.21 \%$. Innovation in agriculture must be supported by the number of researchers with PhDs. Their number is indicated only 35 people, including 18 women (51.4\%). However, this number is decreasing year by year. In 2017, there were 136 researchers with $\mathrm{PhD}$ degrees in agriculture. Clearly, there is a negative trend of little nanofactor influence on agricultural innovation and land endowment (Pokojski, 2020).

To compare the conditions for the use of land resources in countries with economies in transition, it is worth considering the state of the agricultural complex in France, which is currently the breadbasket of Europe.

In 2019, France sold 39,124 million euros worth of agricultural products, a significant figure that implies a multi-billion-dollar profit in this area. Cereal production accounts for $14.8 \%$ of the country's total. Arable land in the country is $329,457 \mathrm{~km}^{2}$. These are the agricultural regions. The intermediate regions cover $258389 \mathrm{~km}^{2}$ the cities cover $50629 \mathrm{~km}^{2}$. A large part of the territory is occupied by agricultural land.

Most agricultural enterprises in France are either small or large $(24.3 \%$ and $21.9 \%$, respectively). Thus, small enterprises are run by family farms and large ones by holding companies such as TNCs or large national companies. The structure of agricultural workers in France is as follows: the total number is 456,000 , of whom $29.7 \%$ are women, 339,110 are owners, 116,690 are family members, and the permanent labor force is 403,750 .

It is obvious that agricultural labor in France is mainly a family business, in which hired workers are intensively involved. Land use is a very important security factor in the development of the national economy and in the system of nano-economic relations. Along with this factor of production, capital is actively used and formed.

\subsection{Evaluation of capital as a factor of production and an indicator of the innovation paradigm}

The consolidated budget of the transition country has grown almost tenfold in 12 years. Security expenditures have consistently exceeded revenues due to the budget deficit, but the latter is gradually decreasing, which could be a positive trend (Melnyk, Leshchukh, 2020).

Lending also increased manifold. The data show that lending in different forms and modes of repayment increased from 71.3 million euros to 128.1 million euros in 2010. If we talk about loans issued by depository corporations (banks) to residents, in 2017, 19020.9 million euros were issued in national currency, as well as 14867.7 million euros in foreign currency. Capital is circulating, and residents are using borrowed funds for business or household life. Loans were issued more than deposits received by banks. Thus, in 2017, household deposits were made in local currency for a total of 8,414.6 million euros and $8,095.8$ million euros in foreign currency.

Another indicator of capital development in a country is investment. The nano-factor of such development is human capital. Capital investment by asset type in transition countries in 2017 amounted to $14,948.7$ million euros, the largest share of which came from machinery, equipment and inventory, in particular $34.5 \%$ of the total, while engineering structures accounted for $17.5 \%$. There has long been a debate in scientific publications about how to attract more funds for industrial development. At present, statistics show that investors in national production are domestic investors who contribute to the modernization of various industries and their safety. Such production should be supported by the development of human capital as a nanoeconomic factor.

Capital investment in professional, scientific, technical activities in 2017 amounted to 265.5 million euros, while 4,776.6 million euros were invested in the industrial sector and 116.4 million euros in education. Education should be self-sufficient and funded by the state, as universities, in addition to the educational system, should develop a component of scientific security with the involvement of promising students and young researchers.

The situation in one of the transition countries should be compared to Great Britain, since it is the country with the most stable currency and a high level of security capital development. Thus, statistics show that in this state budget expenditures exceed revenues. In 2017, revenues were 769 billion pounds and expenditures were 809 billion pounds. The government budget deficit (as a percentage of GDP) was 0.1 in FY 2019-2020 and 0.2 in fiscal year 2020-2021. Public sector net investment (as a percentage of GDP) was 2.2 and 2.6, respectively. It should be noted that the figures are rising, which is a negative trend.

The structure of the expenditure portion of the budget in fiscal year 2019-2020 was as follows:

Health care $-7,1 \%$;

Education - 4,6\%

Housework - 0,7\%

Jurisprudence $-0,5 \%$

Defence - $10,5 \%$

International development - 2,0 \%

Local government - 0,0 \%

Transport - 14,6\%

Business, energy complex, industrial strategy - 11,2\%

Digital economy, culture, media, sport - 0,6 \%

It can be seen that most of the money is spent on transportation and business. Health care and education 
are well-funded, which means government support for the social sectors of the security economy. The nanoeconomy has made significant progress in this island country, where special attention is paid to education (from pre-school to university). People are known to come to Britain from all over the world to get an education. They are children of all ages, from schoolchildren to graduate students.

Another production factor influencing the formation of the innovation paradigm is the availability of human resources (workforce). It is this resource that determines the development of the nanoeconomy. However, while this factor is quantitative, nanoeconomics is mainly characterized by qualitative characteristics.

\subsection{Evaluation of labor resources in the development of innovation systems}

The population of Ukraine as a country with a transitional economic system in 2018 is 42.4 million people, of which $69.3 \%$ are urban and $30.7 \%$ are rural. There are 19558180 men and 22658586 women. Women outnumber men, indicating the fertility potential of our population. It is known that the population of many transition countries is aging, so in 2018 there were 11,725 thousand pensioners. The number of pensioners per 1,000 people in 2018 was 278, compared to 301 in 2011 (Libanova, 2020).

The population is not getting younger because of declining birth rates and rising mortality. In 2017, for example, the natural increase in the population of transition countries was 210.1 thousand people, so it decreased by two hundred and ten thousand inhabitants. The number of live births that year was 364.0 thousand, and the number of deaths was 574.1. Life expectancy at birth in 2017 was 72.0 years, 67.0 years for men and 76.8 years for women. Obviously, men live less than women. The reasons for this statistic are stress, reluctance to go to doctors, etc.

It has been proven in nanoeconomics that life expectancy depends on quality of life. Moreover, married people live longer. For example, in 2017 there were 249,500 marriages with 128,700 divorces. Thus, about $50 \%$ of marriages tend to break up. This is a negative trend, which can significantly affect the performance of the nanoeconomy in the future.

The quality of the labor force is also determined by labor market conditions. The economically active population in a country in transition is declining: from $22,830,800$ in 2000 to $17,854,400$ in 2017 , with women employed less than men at $8,423,800$ and $9,430,600$, respectively. It shows the employment of the population in a country with an economy in transition by type of economic activity (Lipkova, Brockova, Baleha, 2020).
The largest number of employees are employed in the areas of wholesale and retail trade, repair of motor vehicles and motorcycles -3525.8 thousand people. In the sectors of agriculture, forestry and fishing employed 2,860.7 thousand people, in manufacturing $2,440.6$ thousand, in education $-1,423.4$, in health and social assistance - 1,013.6 people. These areas of employment represent the real sector of the security economy, which produces a significant amount of value added.

Italy's population on January 1, 2021 was $59,257,566$, of which $28,846,088$ were men and 30,393478 were women. The natural balance was $-214,333$ people, so there is a decrease in population, and the natural movement is negative. Birth rate is 6.8-7 births per thousand inhabitants (Kichurchak, 2020).

Italy has a very responsible attitude toward the institution of marriage, with couples with children making up the majority of all families in the country, but as the number of family members increases, the number of families decreases. One-person families are becoming more and more popular in this country and its security. The institution of the family follows the religious beliefs of Italians. In 2019 there were 47,400 religious marriages and 52,600 civil marriages. Divorces amounted to 22,087 cases in 2018. Getting a divorce in Italy is quite difficult, and former couples live separately without a de-jure divorce.

The qualitative characteristics of the Italian population are indicators of the development of the labor force. Thus, the workforce in this country in 2020 will be 25,214 thousand people, of whom 22,904 will be employed and 2,310,000 will be unemployed. Human capital is an important resource in Italy, but the high unemployment rate of $9-10 \%$ (according to ILO methodology) is an indicator of a rather mismanaged labor market and lack of employment opportunities outside the family business.

Family business and employment, as well as vocational education, are factors shaping the nanoeconomy in Italy and its innovation paradigm. For Ukraine, this practice can be used to create a nanoeconomy as a holistic security system.

\subsection{Analysis of the intellectual potential of the innovation paradigm}

Workforce is the basis for the formation of the intellectual resource of the security of the national economy. There are some indirect indicators of the intellectual resource, which should include some characteristics of research work. For example, in transition economies, the organizations that performed research work in 2010 were 1,303 institutions, and in 2019 there were 950. 
The number of R\&D workers in 2010 was 182484 (0.95\% of the total) and 79262 in $2019(0.48 \%$ of the total employed population in our state). The downward trend in innovation is a negative phenomenon to describe the innovation paradigm of the nanoeconomy in transitional economies.

The largest volume of S\&T expenditures in some countries of the world is on scientific and technological development $-57.7 \%$ of all research, while basic research accounts for $21.7 \%$. Applied research activity is significant, but insufficiently relevant, although this category of research is the most popular among researchers in the developed countries of the world. Nanoeconomics in such an environment actively influences these securitization processes, as researchers are largely involved in research activities at various levels (Ershova, Obukhova, Belyaeva, 2020).

Intellectual activity is also high in transition economies, as evidenced by the number of organizations that have conducted research by economic activity.

Relevant research institutions are quantitatively larger in terms of R\&D, followed by higher education institutions, which actively conduct research. Under current conditions, it is possible to intensify scientific analysis using the levers of the nanoeconomy, when, for example, students are engaged in promising developments. Experienced specialists become mentors and promote such students to work in laboratories where both basic and applied research is conducted. A country characterized by high activity in the research sector is Germany, and its situation can be compared with the Ukrainian reality.

Thus, the number of workers and researchers in the EU involved in the implementation of $R \& D$ per 1,000 employees in 2017 was in the EU 28-21.6, in Germany - 24.0. The share of research expenditure in GDP on average across the EU in 2017 was EU 28 2.08, in Germany - 3.04, in European transition countries $-0.45 \%$. It is becoming clear that Germany is the flagship of innovative development either in Europe (Bessonova, Battalov, 2020) or in the world. The nanoeconomic component of such development is crucial for the intensification of economic activity at various levels. Thus, the number of researchers, technicians and auxiliary personnel in the total number of employees involved in the implementation of scientific research in 2017 is distributed as follows: Germany, 64.2, 21.4, 14.5\%, respectively; transition country, 63.0, 9.7, 27.3\%, respectively. It can be argued that both countries have the largest number of researchers. As a rule, they have a degree or are trying to obtain one. It should be noted that the European transition country has fewer technical specialists, while Germany has fewer security personnel.

\subsection{Cluster analysis of regional innovation potential in a European country with a transition economy}

As a result of the study, a cluster analysis of Ukrainian regions with the potential for innovative development and the impact of nanotechnology on them was conducted.

K-means clustering was also performed. This is a vector quantization method, which was originally found for signal processing and is often used for cluster analysis of data. K-means clustering aims at dividing $\mathrm{n}$ observations into $\mathrm{k}$ clusters, in which each observation belongs to the cluster with the nearest average (cluster centers or cluster centroid).

The meaning of "proximity" is defined by the Euclidean metric:

$$
\rho(x, y)=x-y=\sqrt{\sum_{i=1}^{n}\left(x_{i}-y_{i}\right)^{2}},
$$

where

$$
x, y \in R^{n}
$$

In this procedure, the number of clusters is unknown and is chosen by the researcher when initializing the algorithm.

In the $\mathrm{R}$ programming language, the k-means function KMeans_arma was selected in the armadillo library of the ClusterR package.

To use KMeans_arma, the number of columns (vector variables) in the data must exceed the number of clusters, otherwise the function will return an error. The algorithm is initialized once, and 10 iterations are usually sufficient for convergence. The output centroids are distributed according to one of the algorithms - keep_existing, static_subset, random_subset, static_spread or random_spread.

Listing:

claster <-read_excel("C:/Users/ASUS1/Desktop/ claster.xlsx") \#data download from Excel to claster array

claster 1<-claster[2:9] \#array construction claster_ 1 without a column with the names of regions

rownames(claster_1) <- claster\$X_1 \#taking claster_1 array column header as region names

install.packages("ClusterR") \#”ClusterR" package installation

library(ClusterR) \#package lib download

$\mathrm{X}=$ claster[2:8] \#data without dependent "regions" variable of claster array

$\mathrm{y}=$ claster[1] \#dependent "region" variable of claster array

dat $=$ center_scale $(X$, mean_center $=\mathrm{T}$, sd_scale $=$ $\mathrm{T})$ \# data scale and centering

pca_dat = stats::princomp $($ dat $) \$$ scores $[, \quad 1: 2]$ \#decrease in the number of measurements in claster data through PCA - principal component analysis

$\mathrm{km}=$ KMeans_arma $($ pca_dat, clusters $=5, \mathrm{n}$ _iter $=$ 10 , seed_mode = "random_subset", 
Table 1

Cluster analysis results

\begin{tabular}{|l|c|c|c|c|c|}
\hline \multicolumn{1}{|c|}{ Regions } & 1cluster & 2cluster & 3cluster & 4cluster & 5cluster \\
\hline Vinnytsia & 0 & 0 & 0 & 1 & 0 \\
\hline Volhynia & 1 & 0 & 0 & 0 & 0 \\
\hline Dnipro & 0 & 0 & 1 & 0 & 0 \\
\hline Donetsk & 1 & 0 & 0 & 0 & 0 \\
\hline Zhytomyr & 1 & 0 & 0 & 0 & 0 \\
\hline Transcarpathia & 0 & 0 & 0 & 1 & 0 \\
\hline Zaporizhzhia & 0 & 1 & 0 & 0 & 0 \\
\hline Ivano-Frankivsk & 0 & 0 & 0 & 1 & 0 \\
\hline Kyiv & 0 & 1 & 0 & 0 & 0 \\
\hline Kirovohrad & 1 & 0 & 0 & 0 & 0 \\
\hline Luhansk & 0 & 0 & 0 & 0 & 1 \\
\hline Lviv & 0 & 0 & 1 & 0 & 0 \\
\hline Mykolaiv & 0 & 1 & 0 & 0 & 0 \\
\hline Odessa & 0 & 1 & 0 & 0 & 0 \\
\hline Poltava & 0 & 0 & 0 & 1 & 0 \\
\hline Rivne & 1 & 0 & 0 & 0 & 0 \\
\hline Sumy & 0 & 1 & 0 & 0 & 0 \\
\hline Ternopil & 1 & 0 & 0 & 0 & 0 \\
\hline Kharkiv & 0 & 0 & 1 & 0 & 0 \\
\hline Kherson & 0 & 0 & 0 & 1 & 0 \\
\hline Khmelnytskyi & 1 & 0 & 0 & 0 & 0 \\
\hline Cherkasy & 0 & 0 & 0 & 1 & 0 \\
\hline Chernivtsi & 0 & 0 & 0 & 1 & 0 \\
\hline Chernihiv & 0 & 0 & 0 & 0 & 1 \\
\hline & & & & & \\
\hline
\end{tabular}

verbose $=\mathrm{T}$, CENTROIDS $=$ NULL) \#5-cluster model construction

$\mathrm{pr}=$ predict_Kmeans (pca_dat, $\mathrm{km}$ ) \#clustering method application to data array

Tab 1<-table(claster\$X 1, pr)\#results recording in the table

write.csv(Tab_1, 'claster_1.csv') \# record of clustering results in 'claster $1 . c s v$ ' file

The results of the cluster analysis are presented in Table 1 . The number " 1 " refers the region to a particular cluster.

A list of clusters is shown in Table 2.

The different values and results of the cluster analysis using the vector quantization method determine that the regional grouping of one of the transition economies has some differences. Thus, the most optimal innovation cluster unites Dnipro, Lviv and Kharkiv regions. Donetsk and Luhansk regions in this method are the constituents of different groups: $1^{\text {st }}$ and $5^{\text {th }}$ clusters. The cluster analysis proves that the groups formed during the time of the Soviet Union are currently being reshaped, and significant differences are being created between the regions of the first cluster -16 regions. Some distinctive features inherent in a smaller number of regions of Ukraine are still evident today. Thus, the regional groups include the regions of different geographical zones of Ukraine where Donetsk is grouped with Volhynia and Khmelnytskyi regions or Sumy - with Zaporizhzhia.
Table 2

List of innovation-resources clusters

\begin{tabular}{|c|c|}
\hline Regions & Clusters \\
\hline Volhynia & \multirow{7}{*}{1 cluster } \\
\hline Donetsk & \\
\hline Zhytomyr & \\
\hline Kirovohrad & \\
\hline Rivne & \\
\hline Ternopil & \\
\hline Khmelnytskyi & \\
\hline Zaporizhzhia & \multirow{5}{*}{2 cluster } \\
\hline Kyiv & \\
\hline Mykolaiv & \\
\hline Odessa & \\
\hline Sumy & \\
\hline Dnipro & \multirow{3}{*}{3 cluster } \\
\hline Lviv & \\
\hline Kharkiv & \\
\hline Vinnytsia & \multirow{7}{*}{4 cluster } \\
\hline Transcarpathia & \\
\hline Ivano-Frankivsk & \\
\hline Poltava & \\
\hline Kherson & \\
\hline Cherkasy & \\
\hline Chernivtsi & \\
\hline Luhansk & \multirow{2}{*}{5 cluster } \\
\hline Chernihiv & \\
\hline
\end{tabular}

It can be stated that the sectors of the economy and innovation spheres of different regions of Ukraine are now becoming interconnected.

\section{Assessment of the intellectual and resource security of the innovative paradigm of nanoeconomics development}

The results justify the formation of an innovation paradigm under the influence of securitization of production factors. The paradigm is analyzed as a condition for the existence of innovation systems in the framework of nanoeconomics.

Paradigms are analyzed as expressions of a particular phenomenon. The method of investigating paradigms through an intellectual-resource security approach makes it possible to assess the basis of the phenomenon and its impact on the nanoeconomy.

Such a study has the following limitations: the lack of statistical information regarding the direct influence of production factors on the nanoeconomy and the innovation paradigm, as well as the limitations of the analysis of the nanoeconomy as a human economy all data are quite subjective in nature.

There is a controversial issue of attributing certain resources to the main factors of production. Their classification as human and capital resources is conditional in determining the development of national economies. 
The innovation paradigm is becoming a determining factor in economic development. However, its resource component can be defined as having an intellectual justification. Thus, labor and technology are direct factors of production that form the innovation paradigm, while capital and land are factors that have an indirect influence on innovative development.

Clustering is an approach to the formation of an innovative paradigm, representing the sustainable development of the national economy using geoindustrial regions (clusters). The question of defining clusters as the basis of regions is still debatable. In particular, can the economy and the nanoeconomy be efficient if both are not cluster-based? This question remains crucial in interpreting the geographical factor as the key to the formation of the nanoeconomy.

\section{Conclusions}

1. The land security resource has a great impact on various areas of the real sectors of the economy, especially agriculture. For agriculture to be effective, the land resource must be innovative for the agrocomplex and land use as a whole. These spheres are related to the development of land science. The role of the nanofactor in land development is also decisive. In transition economies, land innovation is mainly driven by an ecological approach, as farmers use new and environmentally friendly tools. France, the modern breadbasket of Europe, is increasingly adopting science-based agricultural approaches that allow greater yields and the use of fewer chemicals. Countries with economies in transition should follow France's land-use experience. This is agricultural innovation at the level of nanosubjects. The innovation paradigm of the agrocomplex should be based on the individual level of nanoeconomic security.

2. The capital factor has a significant impact on the development of other collateral resources and their use in the productive sectors of the economy. In transition economies, the capitalization of the economy has been at a low level for a long time, since there has not been a constant inflow of foreign investment. At the present stage, the most important investors are national enterprises, which are the source of budget revenues. In transition countries, however, there is a chronic budget deficit, as expenditures exceed revenues. The situation is similar with the budget deficit in Great Britain at the end of the fiscal year, although other indicators of capital development are more positive. Moreover, this country ranks first among the leading countries of the world in international credit ratings. As a factor of production, capital should ensure the self-financing of the nano-economy. Thus, the main investors should be national enterprises and national holders of capital. The owners of financial resources are identified at the nanoscale as private individuals. The presence of the resource of financial security becomes the basis of the innovative component of nanoeconomic development, because national owners have a resource for improving technological production.

3. Workforce, as a factor of production, affects all other aspects of resource development in the economy. It is this resource that determines the individual approach in resource supplying economic development. Thus, land, capital and technological development depend on skilled workers. It is the nanofactor that has a positive influence on the development of the innovation paradigm, forming appropriate conditions for the national economy as a whole. In the countries in transition, the labor resource is the determining factor of the nano-economic system, while in Italy it is the main resource for the development of the national economy as a whole. Thus, Italy is a family-oriented country in the development of business and security economy.

4. The intellectual potential of innovative paradigm development depends on the three main factors described above. It is the resource provision of innovative development of national economies at different levels. In transition countries, the technical component of economic development was inherited from the Soviet era, when the scientific aspect was separated from the entrepreneurial sector. At the present stage of development of market relations, the scientific component is gradually integrated with the production approaches of economic development and with the application of nano-economic basis for the development of more efficient market relations and the economy as a whole. Germany is an example of a country in transition that is generating innovation and using nanofactors to develop optimized safety production processes.

5. The cluster analysis of innovative regions in the countries in transition proves that there is a transition from the model of development of innovative security of the Soviet Union to the market model. Regions are very different, and geographic innovation centers are located in different geographic areas. At the present stage of development of the nano-economy, common features of industrial sectors with a common geographical location are formed, contributing to the further development of the security of the national economy as a whole and its innovation paradigm.

\section{References:}

Arrow, K. J. (1974). Application of management theory to economic growth / Mathematical economy. Moscow: Myr Publishing House, pp. 7-45. Available at: https://archives.lib.duke.edu/catalog/arrow

Bessonova, E., \& Battalov, R. (2020). Digitalization as a tool for innovative economic development. Economic Annals-XXI, no. 186 (11-12), pp. 66-74. DOI: http://doi.org/10.21003/ea 
Bazhal, Yu. (2015). Development of innovation activities within knowledge triangle "government-universityindustry". Economics and prognosis, no. 1, pp. 76-88.

Dziubanovska, N. (2019). Multinational models of studying the EU countries' international trade. Economic Annals-XXI, no. 175 (1-2), pp. 29-34. DOI: http://doi.org/10.21003/ea

Ershova, I., Obukhova, A., \& Belyaeva, O. (2020). Implementation of innovative digital technologies in the world. Economic Annals-XXI, no. 186 (11-12), pp. 28-35. DOI: http://doi.org/10.21003/ea

Kichurchak, M. (2020). Evaluation of cultural sphere development in the European Union countries as a factor of forming social capital and creative industries: experience for Ukraine. Economic Annals-XXI, no. 184 (7-8), pp. 68-78. DOI: http://doi.org/10.21003/ea

Kotko, O. (2016). Innovation ecosystem as a new paradigm of innovative economic development. Odessa National University Herald. Economics, vol. 21, issue 7(1), pp. 52-56. Available at: http://nbuv.gov.ua/UJRN/ Vonu_econ_2016_21_7(1)_13

Libanova, E. (2020). Minimum subsistence level in the social policy of the poor countries of Europe: the case of Ukraine. Economic Annals-XXI, no. 182 (3-4), pp. 117-125. DOI: http://doi.org/10.21003/ea

Lipkova, L., Brockova, K., \& Baleha, A. (2020). Labor migration in Central Asia. Economic factors of influence. Economic Annals-XXI, no. 184 (7-8), pp. 38-48. DOI: http://doi.org/10.21003/ea

Melnyk, M., Leshchukh, I., Medynska, T., \& Rushchyshyn, N. (2020). Potential of the sector of financial services in view of the socio-economic growth of Ukrainian regions. Economic Annals-XXI, no. 185 (9-10), pp. $144-154$.

Nosachevskaya, E., \& Afanasyeva, L. (2019). New trends in the development of the world economy in view of the effects of the emerged crisis. Economic Annals-XXI, no. 186 (11-12), pp. 4-11. DOI: http://doi.org/10.21003/ea Oliynyk-Dunn, O., Wasilewski, M., Wasilewska, N., Okhrimenko, I., \& Adamenko, V. (2020). Transformation of the financing patterns of agricultural enterprises in the condition of the financial system crisis: a case of Ukraine and the USA. Economic Annals-XXI, no. 182 (3-4), pp. 77-89. DOI: http://doi.org/10.21003/ea

Pokojski, Z. (2020). Innovation ecosystem: cooperation of the agricultural market entities in the light of empirical research conducted on the basis of Group Azoty Pulawy innovation consortium. Economic Annals-XXI, no. 185 (9-10), pp. 108-118. DOI: http://doi.org/10.21003/ea

Porter, M. E. (2018). International competition. The competitive advantages of countries. Moscow: Alpina Publisher, 955 p.

Rylach, N. (2016). Formation of innovation paradigm: retrospective and present. Actual problems of international relations. Release 127 (part I) / 206, pp. 138-147.

Schumpeter, J. (2011). Theory of economic development. Kyiv: National University of Kyiv-Mohyla Academy Publishing House, 244 p. Available at: https://nashformat.ua/products/teoriya-ekonomichnogo-rozvytku.doslidzhennya-prybutkiv-kapitalu-kredytu-vidsotka-ta-ekonomichnogo-tsyklu-906036

Tugan-Baranovskiy, M. (1894). Industrial crises in modern England, their reasons and impact on public life. SaintPetersburg: Skorokhodova typology, vol. 1, 512 p. Available at: http://books.google.com.ua/books/about/ Промышленные_кризисы.html

Zabarna, E., \& Kozakova, V. (2019). The paradigm of innovation development in the conditions of market transformation. Kherson: Oldi-plus, $92 \mathrm{p}$.

Zhyhalkevych, Z. (2014). The innovation paradigm of clustering. Economics and enterprise management. Berdyansk University of Management and Business Herald, vol. 2(26), pp. 79-83. 